CLINICAL STUDY

\title{
Investigation of glucocorticoid receptor polymorphisms in relation to metabolic parameters in Addison's disease
}

\author{
I L Ross, N S Levitt, L Van der Merwe ${ }^{1}$, D A Schatz ${ }^{2}$, Johannsson $^{3}$, C Dandara $^{4}$, T S Pillay ${ }^{5}$ and D J Blom ${ }^{6}$ \\ Division of Endocrinology, Department of Medicine, Groote Schuur Hospital, University of Cape Town, J47 Old Main Building, Cape Town 7925 , \\ South Africa, ${ }^{1}$ Biostatistics Unit, South African Medical Research Council, Cape Town, South Africa, ${ }^{2}$ Department of Paediatrics, University of Florida, \\ Gainesville, Florida, USA, ${ }^{3}$ Department of Endocrinology, Institute of Medicine, Sahlgrenska University Hospital, University of Gothenburg, Gothenburg, \\ Sweden, ${ }^{4}$ Department of Human Genetics, ${ }^{5}$ Division of Chemical Pathology, Clinical Laboratory Sciences and NHLS, Groote Schuur Hospital and ${ }^{6}$ Division \\ of Lipidology, Department of Medicine, University of Cape Town, Cape Town, South Africa \\ (Correspondence should be addressed to I L Ross; Email: ian.ross@uct.ac.za)
}

\begin{abstract}
Background: Uncertainty exists whether glucocorticoid receptor (GCR) polymorphisms play a role in steroid-related side effects in Addison's disease (AD) patients on hydrocortisone. The polymorphisms Bcll and N363S appear to increase sensitivity to cortisol, while the ER22/23EK polymorphism has been associated with resistance to cortisol.

Method: One hundred and forty seven AD patients, and gender, and ethnicity-matched controls were recruited in South Africa. Three polymorphisms in the GCR were studied, using PCR followed by restriction fragment length analysis. Associations with BMI, lipids, glucose and inflammatory markers were investigated.

Results: In both patients and controls, the Bcll polymorphism occurred more frequently in whites than in other ethnic groups studied but was not associated with any of the metabolic parameters tested. The ER22/23EK polymorphism was associated with an increased BMI in both patients (29.4 vs $24.7 \mathrm{~kg} / \mathrm{m}^{2}$ ) and control subjects (26.3 vs $24.2 \mathrm{~kg} / \mathrm{m}^{2}$ ). The ER22/23EK polymorphism was also associated with lower LDL cholesterol in control subjects (3.46 vs $3.93 \mathrm{mmol} / \mathrm{l})$ and in patients (3.52 vs $4.10 \mathrm{mmol} / \mathrm{l})$. N363S was associated with increased BMI in controls $29.9 \mathrm{~kg} / \mathrm{m}^{2}$ vs wild type $24.8 \mathrm{~kg} / \mathrm{m}^{2}$. Median hydrocortisone doses were greater in patients heterozygous for either ER $22 / 23 \mathrm{EK}$ $30.0 \mathrm{mg}$ or N363S $25.0 \mathrm{mg}$ polymorphisms than in wild type patients $20.0 \mathrm{mg}$ (both comparisons). Conclusion: Alterations in lipids, BMI and hydrocortisone dose were associated with two polymorphisms. Further larger studies are warranted to corroborate these findings.
\end{abstract}

European Journal of Endocrinology 168 403-412

\section{Introduction}

Addison's disease $(\mathrm{AD})$ patients require lifelong hydrocortisone replacement therapy, but uncertainty exists concerning ideal hydrocortisone doses. Despite physicians' assessments that hydrocortisone supplementation is adequate, many $\mathrm{AD}$ patients report subjective impaired health quality and increased doses are often prescribed, leading to potentially deleterious effects $(1,2,3,4,5,6)$. Elevated total cholesterol (TC) $(7,8,9,10)$, raised triglycerides (TGs) (11, 12), increased LDL cholesterol (LDLC) $(8,9)$ and reduced HDL cholesterol (HDLC) (9) were found in association with glucocorticoids, potentially explaining at least in part why the mortality rate from cardiovascular disease (CVD) is twofold increased in some studies of AD (2).

Cortisol exerts multiple pleotropic actions critical for metabolic, physiological and stress-related conditions (13). The human glucocorticoid receptor (GCR) gene has nine exons, located on chromosome 5 (5q31) (14).
GCR polymorphisms are found throughout the GCR gene and their impact on function is variable, ranging from no impact to either increased or decreased cortisol sensitivity. The Bcll and N363S polymorphisms are reported to increase cortisol sensitivity. Clinical outcomes reported with increased cortisol sensitivity include an increase in BMI of $1.4 \mathrm{~kg} / \mathrm{m}^{2}$ in heterozygotes and $2.0 \mathrm{~kg} / \mathrm{m}^{2}$ in homozygotes in young people (15) for the Bcll polymorphism and an increase in LDLC (16), TG $(16,17), \mathrm{TC}(17,18)$, as well as a higher BMI $(19,20)$ with the N363S polymorphism. The ER22/23EK polymorphism decreases cortisol sensitivity, correlating with a reduction in TC (21), LDL (21) and a lower BMI during pregnancy (22). Altered glucocorticoid sensitivity associated with GCR polymorphisms is a consequence of a modified transcript (23).

Little information exists regarding the role that the GCR polymorphisms may play in the development of glucocorticoid-related side effects in patients receiving hydrocortisone replacement and whether empiric doses 
of hydrocortisone need to be altered in the presence of certain polymorphisms. For example, the ER22/23EK polymorphism is associated with a degree of glucocorticoid resistance (21), yet it is unknown whether increased doses of hydrocortisone are required. If deleterious metabolic consequences are identified in association with the sensitising GCR polymorphisms Bcll (24) and N363S $(25,26)$, genotyping followed by adjustment of hydrocortisone dose according to the genotype may aid management of patients with $\mathrm{AD}$. The aim of this study was to investigate the associations between certain GCR polymorphisms and metabolic and inflammatory markers in groups of $\mathrm{AD}$ patients and healthy controls.

\section{Materials and methods}

\section{Subjects and methods}

This study was approved by the University of Cape Town Human Research and Ethics Committee and all participants signed informed consent. We included $147 \mathrm{AD}$ patients and 147 age-, gender- and ethnicitymatched healthy controls who attended a volunteer blood donor clinic. AD patients were recruited from a South African national database, in which all medical practitioners were asked to register patients with $\mathrm{AD}$ under their care. Clinical data were extracted from patients' notes and patient interviews. Blood was taken in a non-fasting state for DNA extraction, plasma lipid determination and measurement of CVD risk markers.

\section{Hydrocortisone dose}

Hydrocortisone doses were modified by the patients' treating physicians based on symptoms suggestive of either hypoadrenalism or cortisol excess. There were no standard protocols to modify replacement doses. The majority of patients received a dose of $\sim 20 \mathrm{mg}$ hydrocortisone per day, irrespective of body weight. As this was an observational study, the authors had no influence on hydrocortisone dosing. Only ambulatory, well patients with $\mathrm{AD}$ on stable doses of hydrocortisone replacement for a minimum of 3 months were included in this study. Careful review of concomitant medication was undertaken to ensure that the hydrocortisone dose was not influenced by drugs known to induce or inhibit hydrocortisone metabolism.

\section{Assays for lipids, lipoproteins and markers of cardiovascular risk}

Assays for TG, TC, non-esterified fatty acids (NEFA) and random blood glucose (RBG) were carried out with commercially available enzymatic kits, using standard curves and calibrators. The respective kits for TG, TC, NEFA and RBG were KAT TGs (category number T801- glycerol-3-phosphate-oxidase method), KAT cholesterol (category number CH704-cholesterol-oxidase method), Roche free fatty acids (category number 11383175001-acyl-CoA-synthetase) and KAT glucose (category number GP747-glucose-oxidase method). HDLC was measured following the first step in the Gidez assay (27), which yields HDLC in the supernatant of a heparin-Mn precipitation of apoB-containing lipoproteins. LDL particle size was measured by nondenaturing gradient gel electrophoresis. LDLC was calculated by the Friedewald equation (28).

Highly sensitive C-reactive protein (hs-CRP) was measured using an immunoturbidimetric assay (Roche Diagnostics $\mathrm{GmbH}$ ), demonstrating a coefficient of variation of 4 and $3 \%$ at serum concentrations of 1 and $15 \mathrm{mg} / \mathrm{l}$ respectively. Framingham risk was calculated using an algorithm that includes diabetes as a risk factor so that comparisons could be made across the entire cohort (29). Currently, diabetes is regarded as a secondary prevention equivalent for CVD and is not included as a risk factor in the Framingham algorithm any longer (30).

\section{DNA extraction}

Genomic DNA purification was performed using a Promega wizard kit, as published previously (31).

\section{Detection of the GCR single nucleotide poly- morphisms: Bcll, ER22/23EK and N363S}

Genotyping of the GCR gene for detecting the single nucleotide polymorphism (SNP) changes Bcll G/C (RS41423247), ER22/23EK AA/GG (rs6189) and N363S G/A (rs6195) was performed by PCR amplification, followed by restriction fragment length analysis. Primers were designed using Oligo.exe (National Biosciences, Plymouth, MN, USA). Primer pairs used in the PCR amplification are shown in Table 1. Each PCR contained $~ 100-500 \mathrm{ng} / \mu \mathrm{l}$ genomic DNA, $1 \times \mathrm{PCR}$ buffer, $1.5 \mathrm{mM} \mathrm{MgCl}_{2}, 200 \mu \mathrm{M}$ dNTP and $15 \mathrm{pM}$ of each primer 0.75 U Taq DNA polymerase (Promega-Go Taq Flexi DNA polymerase) in a final volume of $30 \mu \mathrm{l}$. PCR conditions for all the reactions were the same. The denaturation step was performed at $98^{\circ} \mathrm{C}$ for $2 \mathrm{~min}$, followed by 35 cycles of denaturation at $94{ }^{\circ} \mathrm{C}$ for $30 \mathrm{~s}$ and annealing was carried out at $52{ }^{\circ} \mathrm{C}$ for $30 \mathrm{~s}$. Elongation occurred at $72{ }^{\circ} \mathrm{C}$ for $30 \mathrm{~s}$ and a final extension occurred at $72{ }^{\circ} \mathrm{C}$ for $8 \mathrm{~min}$. rs 41423247 PCR products were digested using $\mathrm{Bcll}$ restriction enzyme $(\mathrm{C}$ allele $=$ $146+86 \mathrm{bp}, \mathrm{G}$ allele $=232 \mathrm{bp}$ ), rs6189 PCR products were digested using $\mathrm{Mn} 1$ restriction enzyme (GAG AGG allele $=201+143+50+35+15+11+3 \mathrm{bp}$, GAA AAG allele $=201+178+50+11+3 \mathrm{bp})$ and rs6195 PCR products were digested using Tsp 5091 $($ A allele $=91+36 \mathrm{bp}, \mathrm{G}$ allele $=127 \mathrm{bp})$. Products were separated on an agarose gel, visualised with ethidium bromide and fragment sizes were compared with standard markers (1 kB plus (Promega)). 
Table 1 Primer pairs used for the detection of SNPs of the GCR.

\begin{tabular}{lll}
\hline Polymorphism & SNP & Primer sequences \\
\hline Bch G/C & rs41423247 & F: $5^{\prime}$-GCA GTG AAC AGT GGT ACC AGA CC-3' \\
& R: $5^{\prime}$-AAA GAG AAA AAT CAA ACG AA GC-3' \\
ER22/23EK AA/GG & rs6189 & F: $5^{\prime}$-GCT GCC TCT TAC TAA TCG GAT CA-3' \\
N363S G/A & R: 5'-TTT AAG TCT GTT TCC CCC GAG-3' \\
& rs6195 & F: 5'-TTT AAT GTC ATT CCA CCT ATT CCC-3' \\
& & R: $5^{\prime}$-AGC CAT TAG AAA AAA CTG TTC GAC-3' \\
\hline
\end{tabular}

GCR, glucocorticoid receptor; SNP, single nucleotide polymorphism; rs, reference SNP.

Genotyping quality was verified using the HardyWeinberg equilibrium (HWE) calculations on the controls, with none of the genotypes deviating from HWE, as shown by their respective $P$ values in parentheses: $B c l l$ (0.11), N363S (1.00) and ER22/23EK (1.00). Samples were not sequenced for other GCR polymorphisms.

\section{Statistical analysis}

Logistic regression was used for all comparisons between patients and controls, enabling us to control for possible confounders such as age and gender. Characteristics and polymorphism prevalence were compared between patients and controls, adjusting for age, gender and ethnicity (unadjusted comparisons were made for adjustment variables). We used general linear models to investigate whether the polymorphism had an effect on numerical characteristics or phenotypes (like TG or TC, transformed to symmetry when required) in healthy controls and in patients. Logistic regression models were used to assess the effect of the polymorphisms on dichotomous characteristics such as the presence or absence of small dense LDL particles. In healthy controls, these analyses were adjusted for BMI, age, gender and ethnicity, and for patients, the analyses were adjusted for BMI, age, gender, ethnicity, foreign ancestry and hydrocortisone dose, where possible. Further analyses assessed whether the effect of the polymorphisms differed between patients and controls (interaction). Interaction analyses were adjusted for BMI, gender, age and ethnicity. We repeated the analyses of all lipid parameters after excluding all patients on lipid-lowering therapy and also noted an extreme outlier amongst the TSH results $(31.2 \mathrm{mIU} / \mathrm{l})$ in a patient who was non-compliant with thyroxine replacement and excluded this value from analyses of the TSH data set. 'R: A language and environment for statistical computing', freely available from http://www. R-project.org/and R package genetics, was used for all statistical analyses. We regarded $P$ values below 0.05 as statistically significant. For the polymorphisms with low frequency, only descriptive data are shown.

\section{Results}

Patients and controls were well matched for gender and ethnicity but patients had lower BMI. Patients had more atherogenic lipid profiles, as evidenced by a preponderance of small dense LDL, higher TG, lower HDLC and higher hs-CRP levels (Table 2). None of the

Table 2 Clinical characteristics in Addison's disease patients and controls.

\begin{tabular}{|c|c|c|c|}
\hline Clinical characteristics & Patients $(n=147)$ & Controls $(n=147)$ & $P$ value \\
\hline Age (years), median (IQR) & $46.0(33.5-61.0)$ & $41.5(33.0-53.0)$ & 0.108 \\
\hline \multicolumn{4}{|l|}{ Gender ( $n(\%))$} \\
\hline Female & $90(61)$ & $90(61)$ & \multirow[t]{2}{*}{1.000} \\
\hline Male & 57 (39) & 57 (39) & \\
\hline \multicolumn{4}{|l|}{ Ethnicity $(n(\%))$} \\
\hline White & $97(66)$ & $97(66)$ & \multirow[t]{4}{*}{1.000} \\
\hline Mixed ancestry & $34(23)$ & $34(23)$ & \\
\hline Asian & $5(3)$ & $5(3)$ & \\
\hline Black & $11(7)$ & $11(7)$ & \\
\hline BMI $\left(\mathrm{kg} / \mathrm{m}^{2}\right)$, median (IQR) & $24.7(22.1-30.3)$ & $26.4(24.1-31.2)$ & 0.001 \\
\hline $\mathrm{TG}(\mathrm{mmol} / \mathrm{l})$, median (IQR) & $1.67(1.1-2.61)$ & $1.39(0.97-2.13)$ & 0.011 \\
\hline TC (mmol/l), mean (S.D.) & $5.70(1.55)$ & $5.77(1.26)$ & 0.226 \\
\hline HDLC (mmol/l), median (IQR) & $0.78(0.53-1.07)$ & $1.08(0.93-1.27)$ & $<0.001$ \\
\hline LDLC (mmol/l), mean (s.D.) & $4.07(1.37)$ & $3.89(1.17)$ & 0.599 \\
\hline Small dense LDL ( $n(\%))$ & $17 / 147(12)$ & 5/147 (3) & 0.001 \\
\hline NEFA ( $\mu \mathrm{mol} / \mathrm{l})$, median (IQR) & $341.0(142.5-654.0)$ & $467.0(325.8-644)$ & $<0.001$ \\
\hline Lipid-lowering therapy $(n(\%))$ & 19/147 (13) & $0(0)$ & \\
\hline hs-CRP (mg/l), median (IQR) & $2.2(0.97-6.38)$ & $1.5(0.64-3.25)$ & 0.024 \\
\hline
\end{tabular}

TG, triglyceride; HDLC, HDL cholesterol; LDLC, LDL cholesterol; NEFA, non-esterified fatty acid; IQR, interquartile range. $P$ value: comparison between patients vs controls, adjusted for age, gender, race and BMI. Statistically significant differences are in boldface. 
controls were on lipid-lowering therapy, in contrast to $19(13 \%)$ of the patients.

\section{Hydrocortisone dose}

The median (interquartile range) dose of hydrocortisone adjusted for body weight was $0.33(0.25-0.45) \mathrm{mg} / \mathrm{kg}$. Most patients were taking doses between 0.2 and $0.4 \mathrm{mg} / \mathrm{kg}$, but a few were taking substantially higher doses. We detected no significant correlation between total daily hydrocortisone dose and duration of $\mathrm{AD}$ $(r=0.13 ; P=0.15)$.

\section{Linkage disequilibrium}

There was significant linkage disequilibrium (D') between the Bcll ( $\mathrm{G}$ allele) and the N363S (G allele) polymorphisms in $\mathrm{AD}$ patients $\left(P=0.03 ; D^{\prime}=1.0\right)$, which was not observed in controls $(P=0.93$; $\left.D^{\prime}=0.05\right)$. There was a weak association for the $\mathrm{G}$ allele of the Bcll and the GAA AAG allele of the ER22/23EK polymorphism in AD patients $(P=0.07$; $D^{\prime}=1.0$ ), but there was no linkage of the $\mathrm{G}$ allele of the N363S and the GAA AAG allele of the ER22/23EK in either $\mathrm{AD}$ patients or controls.

\section{Clinical characteristics associated with the Bcll (G allele) polymorphism in healthy controls and patients}

Age and gender were not different among healthy controls of different genotypes (Table 3). In healthy controls, there were ethnic differences in the distribution of the genotypes. Among white healthy controls, the most prevalent genotype was the wild type CC genotype in 44\%, while among healthy Asian and black controls, the heterozygous genotype (CG allele) was observed less often than in their white and mixed ancestry counterparts. There were no ethnic differences in the distribution of the Bcll genotypes among patients, but there were ethnic differences in $B c l l$ distribution between the patients compared with the controls.

Among healthy controls, there were no differences in TC, TG, HDLC, LDLC, NEFA, hs-CRP and the proportion with small dense LDL among those who had at least one $\mathrm{G}$ allele, compared with the wild type (two $\mathrm{C}$ alleles). In AD patients, there were no differences in the prevalence of hypertension, diabetes and use of lipidlowering therapy. The TC, TG, HDLC, LDLC, the proportion with small dense LDL, NEFA, hs-CRP, Framingham risk and hydrocortisone dose did not differ between those who harbour at least one $\mathrm{G}$ allele and the wild type (two $\mathrm{C}$ alleles). Comparison between $\mathrm{AD}$ patients and healthy controls revealed that the $\mathrm{Bcll}$ association with TC, LDLC, small dense LDL, TG, HDLC, NEFA and hs-CRP did not differ. There was, however, a trend towards a greater BMI in controls compared with the patients with respect to at least one Bcll $\mathrm{G}$ allele. Overall, the Bcll (G allele) had minimal effect on the clinical phenotype in both patients and healthy controls.

\section{Clinical characteristics associated with the ER22/23EK (GAA AAG base changes) polymorphisms in healthy controls and in patients with Addison's disease}

Only limited numbers of patients $(n=7)$ and controls $(n=10)$ with the ER22/23EK polymorphism (GAA AAG base changes) were identified (Table 4). The ages of heterozygous patients and controls 43.0 (42.0-46.5) years and 40.5 (29.0-47.0) years were similar to the ages of the wild type patients and controls 46.0 (31.0-61.0) years and 42.0 (33.0-53.0) years respectively. The BMI of heterozygous patients $29.4(28.1-35.4) \mathrm{kg} / \mathrm{m}^{2}$ and controls $26.3(23.9-30.6) \mathrm{kg} / \mathrm{m}^{2}$ was greater than that of the wild type patients $24.7(22.1-30.0) \mathrm{kg} / \mathrm{m}^{2}$ and controls $24.2(22.8-28.0) \mathrm{kg} / \mathrm{m}^{2}$ respectively and differed in both cases by more than $2 \mathrm{~kg} / \mathrm{m}^{2}$. Hypertension and diabetes occurred less frequently in the heterozygous patients than in patients exhibiting the wild type. Both the heterozygous patients and controls exhibited higher TGs than their wild type counterparts, $2.17(1.55-3.1) \mathrm{mmol} / \mathrm{l}$ and 1.77 (1.41-1.92) mmol/l vs $1.67(1.10-2.53) \mathrm{mmol} / \mathrm{l}$ and $1.34(0.95-2.14) \mathrm{mmol} / \mathrm{l}$ respectively. The HDLC did not appear to be affected by the presence of the ER22/23EK polymorphism. Heterozygous patients and controls had lower LDLC than the wild types, 3.52 (0.78) $\mathrm{mmol} / \mathrm{l}$ and $3.46(0.51) \mathrm{mmol} / \mathrm{l}$ vs 4.10 (1.39) $\mathrm{mmol} / \mathrm{l}$ and $3.93(1.20) \mathrm{mmol} / \mathrm{l}$ respectively. The heterozygous patients and controls exhibited higher hs-CRP 5.0 (3.4-8.05) $\mathrm{mg} / \mathrm{l}$ and 4.2 (1.1-7.2) $\mathrm{mg} / \mathrm{l}$ than their wild type counterparts 2.2 (1.03-6.40) $\mathrm{mg} / \mathrm{l}$ and 1.5 (0.60-2.85) mg/l respectively. Heterozygous patients received a higher dose of hydrocortisone 30.0 (25.0-30.0) mg compared with the wild type patients $20.0(20.0-30.0) \mathrm{mg}$.

\section{Clinical characteristics associated with the N363S (A to G base change) polymorphism in healthy control subjects and patients with $A D$}

There were limited numbers of heterozygous patients $(n=10)$ and controls $(n=7)$ with the N363S polymorphism (Table 5). The heterozygous patients 31.5 (23.3-44.8) years appeared to be younger than the patients with wild type 41.0 (34.3-60.8) years, but the heterozygous controls were older 49.0 (40.5-49.3) years than the wild type controls 41.0 (33.0-53.0) years. The BMI was similar in heterozygous 25.9 (22.9-27.2) $\mathrm{kg} / \mathrm{m}^{2}$ and wild type patients 24.8 (22.1-30.4) $\mathrm{kg} / \mathrm{m}^{2}$, but in controls, the BMI was 
Table 3 Analysis of the effect of the Bch (C to G base change) in healthy control subjects and patients with Addison's disease.

\begin{tabular}{|c|c|c|c|c|c|c|}
\hline \multirow[b]{2}{*}{ Characteristics } & \multirow[b]{2}{*}{ Homozygous } & \multirow[b]{2}{*}{ Heterozygous } & \multirow[b]{2}{*}{ Wild type } & \multicolumn{3}{|c|}{$P$ value } \\
\hline & & & & Controls $^{a}$ & Patients $^{b}$ & Interaction $^{c}$ \\
\hline \multicolumn{7}{|l|}{ Group ( $n$ (freq)) } \\
\hline Controls & $17(0.12)$ & $53(0.36)$ & $77(0.52)$ & & & 0.122 \\
\hline Patients & $11(0.08)$ & $67(0.48)$ & $63(0.44)$ & & & \\
\hline \multicolumn{7}{|c|}{ Age (years), median (IQR) } \\
\hline Controls & $46.5(26.0-54.0)$ & $41.0(32.0-52.5)$ & $41.0(34.0-53.0)$ & 0.674 & 0.192 & 0.328 \\
\hline Patients & $30.0(20.5-50.5)$ & $45.0(47.0-59.5)$ & $50.5(34.0-63.8)$ & & & \\
\hline \multicolumn{7}{|l|}{ Gender } \\
\hline \multicolumn{7}{|l|}{ Female (freq) } \\
\hline Controls & $11(0.12)$ & $34(0.38)$ & $45(0.50)$ & 0.767 & 0.537 & 0.424 \\
\hline Patients & $6(0.07)$ & $39(0.45)$ & $42(0.48)$ & & & \\
\hline \multicolumn{7}{|l|}{ Male (freq) } \\
\hline Controls & $6(0.11)$ & $19(0.33)$ & $32(0.56)$ & & & \\
\hline \multirow{2}{*}{\multicolumn{7}{|c|}{ BMI $\left(\mathrm{kg} / \mathrm{m}^{2}\right)$, median (IQR) }} \\
\hline & & & & & & \\
\hline Controls & $29.4(24.9-31.5)$ & $26.0(24.3-30.1)$ & $26.5(20.6-31.6)$ & 0.228 & 0.107 & 0.052 \\
\hline Patients & $22.5(21.5-22.6)$ & $25.0(21.5-29.9)$ & $27.4(23.5-30.6)$ & & & \\
\hline \multicolumn{7}{|c|}{ Hypertensive ( $n$ (freq)) } \\
\hline Patients & $0(0)$ & $14(0.64)$ & $8(0.36)$ & - & 0.331 & - \\
\hline \multicolumn{7}{|l|}{ Diabetic ( $n$ (freq)) } \\
\hline Patients & $1(0.05)$ & $11(0.55)$ & $8(0.40)$ & - & 0.349 & - \\
\hline \multicolumn{7}{|c|}{$\mathrm{TG}(\mathrm{mmol} / \mathrm{l})$, median $(\mathrm{IQR})$} \\
\hline Controls & $1.28(1.08-1.75)$ & $1.31(0.92-1.92)$ & $1.42(0.98-2.15)$ & 0.875 & 0.230 & 0.343 \\
\hline \multirow{2}{*}{\multicolumn{7}{|c|}{ TC (mmol/l), mean (S.D.) }} \\
\hline & & & & & & \\
\hline Controls & $5.92(0.98)$ & $5.86(1.27)$ & $5.67(1.30)$ & 0.719 & 0.786 & 0.852 \\
\hline Patients & $5.94(2.27)$ & $5.65(1.65)$ & $5.74(1.35)$ & & & \\
\hline \multicolumn{7}{|c|}{ HDLC (mmol/l), median (IQR) } \\
\hline Controls & 1.15 (1.09-1.37) & $1.07(0.91-1.37)$ & $1.06(0.97-1.2)$ & 0.771 & 0.707 & 0.489 \\
\hline Patients & $0.68(0.58-0.91)$ & $0.7(0.54-0.98)$ & $0.86(0.51-1.16)$ & & & \\
\hline \multicolumn{7}{|c|}{ LDLC (mmol/l), median (IQR) } \\
\hline Controls & $3.93(1.0)$ & $3.82(1.13)$ & $3.95(1.21)$ & 0.977 & 0.976 & 0.955 \\
\hline Patients & $4.36(1.26)$ & $4.02(1.60)$ & $4.09(1.07)$ & & & \\
\hline \multicolumn{7}{|c|}{ Small dense LDL ( $n$ (freq)) } \\
\hline Controls & $0(0)$ & $2(0.40)$ & $3(0.60)$ & 0.506 & 0.264 & 0.990 \\
\hline Patients & $0(0)$ & $12(0.71)$ & $5(0.29)$ & & & \\
\hline \multicolumn{7}{|c|}{ NEFA ( $\mu \mathrm{mol} / \mathrm{l})$, median (IQR) } \\
\hline Controls & $622(388-940)$ & $444(280-576)$ & $467(327-642)$ & 0.118 & 0.129 & 0.281 \\
\hline Patients & $349(196-448)$ & $226(85-566)$ & $417(179-707)$ & & & \\
\hline \multicolumn{7}{|c|}{ Lipid-lowering (n (freq)) } \\
\hline $\begin{array}{l}\text { Patients } \\
\text { hs-CRP }(\mathrm{mg} / \mathrm{l}), \mathrm{m}\end{array}$ & $2(0.11)$ & $9(0.47)$ & $8(0.42)$ & - & 0.743 & - \\
\hline Controls & $2.2(0.85-1.5)$ & $1.35(0.60-2.28)$ & $1.55(0.71-3.55)$ & 0.338 & 0.749 & 0.359 \\
\hline Patients & $0.54(0.19-2.1)$ & $1.65(0.97-3.0)$ & $1.9(1.14-7.4)$ & & 0.170 & 0.035 \\
\hline Hydrocortisone (n & QR) & & & & & \\
\hline Patients & $25.0(13.1-30.0)$ & $23.8(20.0-30.0)$ & $20.0(15.0-30.0)$ & - & 0.742 & - \\
\hline Framingham, mec & & & & & & \\
\hline Patients & $12.0(5.3-22.0)$ & $14.4(8.0-27.4)$ & $13.0(4.3-21.9)$ & - & 0.395 & - \\
\hline $\mathrm{TSH}(\mathrm{mlU} / \mathrm{l}), \mathrm{med}$ & & & & & & \\
\hline Patients & $1.23(0.90-2.46)$ & $1.21(0.50-1.91)$ & $1.66(0.93-2.18)$ & - & 0.199 & - \\
\hline
\end{tabular}

$P$ values for the number, age, gender and ethnicity were unadjusted.

${ }^{a} P$ value: controls comparing characteristics between $B c /$ genotypes among control subjects, adjusted for BMI, age, gender and ethnicity.

${ }^{\mathrm{b}} P$ value: patients comparing characteristics between $B c /$ genotypes among Addison's patients, adjusted for BMI, age, gender, ethnicity, foreign ancestry and hydrocortisone dose per metre squared.

${ }^{c} P$ value: interaction joint comparison of characteristics between $B c h$ genotypes and between Addison's patients and healthy control subjects (interaction), adjusted for BMI, age, gender and ethnicity.

greater in heterozygotes $29.9(26.5-31.0) \mathrm{kg} / \mathrm{m}^{2}$ than in those harbouring the wild type 24.8 (22.1-30.4) $\mathrm{kg} / \mathrm{m}^{2}$. The TG, TC, HDLC, LDLC and proportions of small dense LDL did not appear to be affected by this polymorphism. The hydrocortisone dose appeared to be greater in heterozygous patients 25.0 (20.0-30.0) mg vs wild types $20.0(20.0-30.0) \mathrm{mg}$.

\section{Discussion}

Our novel study examined GCR polymorphisms in patients with $\mathrm{AD}$ and their correlation with dose of hydrocortisone or metabolic parameters, apart from a very recent publication (32). Elevated BMI, TGs and hs-CRP but lower LDLC in healthy controls and patients 
Table 4 Analysis of the effect of the presence of the ER22/23EK (GAG AGG to GAA AAG base changes) polymorphism in healthy controls and in patients with Addison's disease.

\begin{tabular}{|c|c|c|}
\hline Characteristics & Heterozygous & Wild type \\
\hline \multicolumn{3}{|l|}{ Group ( $n$ (freq)) } \\
\hline Controls & $10(0.07)$ & $136(0.93)$ \\
\hline Patients & $7(0.05)$ & $134(0.95)$ \\
\hline \multicolumn{3}{|c|}{ Age (years), median (IQR) } \\
\hline Controls & $40.5(29.0-47.0)$ & $42.0(33.0-53.0)$ \\
\hline Patients & $43.0(42.0-46.5)$ & $46.0(31.0-61.0)$ \\
\hline \multicolumn{3}{|l|}{ Gender } \\
\hline \multicolumn{3}{|l|}{ Female (freq) } \\
\hline Controls & $7(0.08)$ & $83(0.92)$ \\
\hline Patients & $6(0.07)$ & $81(0.93)$ \\
\hline \multicolumn{3}{|l|}{ Male (freq) } \\
\hline Controls & $3(0.05)$ & $54(0.95)$ \\
\hline Patients & $1(0.02)$ & $53(0.98)$ \\
\hline \multicolumn{3}{|c|}{$\mathrm{BMI}\left(\mathrm{kg} / \mathrm{m}^{2}\right)$, median (IQR) } \\
\hline Controls & $26.3(23.9-30.6)$ & $24.2(22.8-28.0)$ \\
\hline Patients & $29.4(28.1-35.4)$ & $24.7(22.1-30.0)$ \\
\hline \multicolumn{3}{|c|}{ Hypertensive ( $n$ (freq)) } \\
\hline Patients & $0(0)$ & $21(1)$ \\
\hline \multicolumn{3}{|l|}{ Diabetic ( $n$ (freq)) } \\
\hline Patients & $0(0)$ & $20(1)$ \\
\hline \multicolumn{3}{|c|}{$\mathrm{TG}(\mathrm{mmol} / \mathrm{l})$, median (IQR) } \\
\hline Controls & $1.77(1.41-1.92)$ & $1.34(0.95-2.14)$ \\
\hline Patients & $2.17(1.55-3.1)$ & $1.67(1.10-2.53)$ \\
\hline \multicolumn{3}{|c|}{ TC (mmol/l), mean (S.D.) } \\
\hline Controls & $5.48(0.53)$ & $5.79(1.30)$ \\
\hline Patients & $5.27(0.97)$ & $5.75(1.57)$ \\
\hline \multicolumn{3}{|c|}{ HDLC (mmol/l), median (IQR) } \\
\hline Controls & $1.11(1.06-1.27)$ & $1.07(0.92-1.27)$ \\
\hline Patients & $0.72(0.53-0.86)$ & $0.78(0.54-1.09)$ \\
\hline \multicolumn{3}{|c|}{ LDLC (mmol/l), mean (s.D.) } \\
\hline Controls & $3.46(0.51)$ & $3.93(1.20)$ \\
\hline Patients & $3.52(0.78)$ & $4.10(1.39)$ \\
\hline \multicolumn{3}{|c|}{ Small dense LDL ( $n$ (freq)) } \\
\hline Controls & $0(0)$ & $5(1.00)$ \\
\hline Patients & $2(0.12)$ & $15(0.88)$ \\
\hline \multicolumn{3}{|c|}{ NEFA $(\mu \mathrm{mol} / \mathrm{l})$, median (IQR) } \\
\hline Controls & $550.0(365.0-681.0)$ & $458.0(328.0-642.0)$ \\
\hline Patients & $450.0(192.0-658.0)$ & $329.0(139.0-654.0)$ \\
\hline \multicolumn{3}{|c|}{ Lipid-lowering ( $n$ (freq)) } \\
\hline \multirow{2}{*}{\multicolumn{3}{|c|}{ hs-CRP (mg/l), median (IQR) }} \\
\hline & & \\
\hline Controls & $4.20(1.10-7.20)$ & $1.50(0.62-2.85)$ \\
\hline Patients & $5.00(3.40-8.05)$ & $2.20(1.03-6.3)$ \\
\hline \multicolumn{3}{|c|}{ Hydrocortisone (mg), median (IQR) } \\
\hline Patients & $30.0(25.0-30.0)$ & $20.0(20.0-30.0)$ \\
\hline \multicolumn{3}{|c|}{ Framingham, median (IQR) } \\
\hline Patients & $9.0(3.1-16.7)$ & $13.3(5.9-25.7)$ \\
\hline \multicolumn{3}{|c|}{ TSH (mlU/I), median (IQR) } \\
\hline Patients & $1.10(0.56-1.38)$ & $1.46(0.78-2.16)$ \\
\hline
\end{tabular}

were associated with the ER22/23EK polymorphism. Patients heterozygous for either the ER22/23EK or the N363S polymorphism appeared to require higher doses of hydrocortisone. We have also shown that $\mathrm{AD}$ patients demonstrated higher TG, lower HDLC concentrations, a preponderance of small dense LDL and raised hs-CRP, despite having a lower BMI than controls. These intriguing findings may account for the twofold CVD risk previously described in $\mathrm{AD}$ patients (2).

The Prospective Cardiovascular Münster Heart (PROCAM) study, for example, showed an association between CVD and TG, independent of LDLC and HDLC (33). TG concentrations are influenced by multiple factors including increasing age, BMI, waist-to-hip ratio, dysglycaemia, drugs and hypothyroidism (34). $\mathrm{AD}$ patients may be predisposed to elevated TG independently of these aforementioned factors, possibly as hydrocortisone may increase VLDL production, thereby raising TG concentration $(7,11)$.

Low HDLC in AD patients could be explained by aged or improper handling of samples, but the same methods were utilised in controls. Low HDLC was found in critically ill patients with adrenal dysfunction. Apolipoprotein AI concentration is also reduced along with HDLC in the acute phase (35). Beentjes et al. showed that hypopituitary patients who were not supplemented with $\mathrm{GH}$, and were evaluated before and after receiving hydrocortisone replacement, had decreased plasma cholesterol esterification when given hydrocortisone, and thus, HDL production may be impaired in $\mathrm{AD}$ in the same way. Hydrocortisone decreases LCAT activity, explaining this phenomenon (36).

$\mathrm{AD}$ patients had more small dense LDL particles compared with controls, which may be a further contributing factor towards the observed increase in CVD mortality. Small dense LDL particles enter arterial tissue more easily than larger LDL particles, predisposing towards atherosclerosis. Small dense LDL particles are also more susceptible to oxidation. When small dense LDL predominates, it confers a three- to sevenfold increased risk of CVD (37).

CRP is an acute-phase reactant protein and CRP concentration can increase dramatically following tissue necrosis and inflammation. In the absence of an acute-phase reaction, variations in 'baseline' CRP, detected using a highly sensitive assay, are predictive of CVD risk (38). The significance of elevated CRP needs to be investigated in long-term studies of $\mathrm{AD}$ patients to determine whether it translates into accelerated CVD. Precise causes of atherogenic dyslipidaemia in this cohort and whether these relate to hydrocortisone doses are unknown but it is intriguing that $\mathrm{AD}$ patients exhibit worse CVD risk, despite a lower BMI.

We observed significant linkage disequilibrium between the Bcll and N363S polymorphisms in patients but not in controls and the results of this analysis should not be over-interpreted, given the small dataset and heterogeneous groups, and the possibility of random effects. No evidence of coexistent competing GCR polymorphisms was found in the same patient.

The Bcll polymorphism was not associated with any metabolic alteration in our study. As GCR polymorphisms only modestly alter the phenotype, it is not surprising that the Bcll polymorphism did not affect the phenotype measurably, as other studies have also not demonstrated meaningful associations $(39,40,41,42)$.

The ER 22/23EK polymorphism was associated with an elevated BMI in healthy controls and patients. 
Table 5 Analysis of the effect of the presence of N363S (A to $\mathrm{G}$ base change) polymorphisms in healthy controls and in patients with Addison's disease.

\begin{tabular}{|c|c|c|}
\hline Characteristics & Heterozygous & Wild type \\
\hline \multicolumn{3}{|l|}{ Group ( $n$ (freq)) } \\
\hline Controls & $7(0.05)$ & $140(0.95)$ \\
\hline Patients & $10(0.07)$ & $131(0.93)$ \\
\hline \multicolumn{3}{|c|}{ Age (years), median (IQR) } \\
\hline Controls & $49.0(40.5-49.3)$ & $41.0(33.0-53.0)$ \\
\hline Patients & $31.5(23.3-44.8)$ & $41.0(34.3-60.8)$ \\
\hline \multicolumn{3}{|l|}{ Gender } \\
\hline \multicolumn{3}{|l|}{ Female (freq) } \\
\hline Controls & $3(0.03)$ & $87(0.97)$ \\
\hline Patients & $5(0.06)$ & $82(0.94)$ \\
\hline \multicolumn{3}{|l|}{ Male (freq) } \\
\hline Controls & $4(0.07)$ & $53(0.93)$ \\
\hline Patients & $5(0.09)$ & $49(0.91)$ \\
\hline \multicolumn{3}{|c|}{ BMI $\left(\mathrm{kg} / \mathrm{m}^{2}\right)$, median $(\mathrm{IQR})$} \\
\hline Controls & $29.9(26.5-31.0)$ & $24.8(22.1-30.4)$ \\
\hline Patients & $25.9(22.9-27.2)$ & $24.8(22.1-30.4)$ \\
\hline \multicolumn{3}{|c|}{ Hypertensive ( $n$ (freq)) } \\
\hline Patients & $2(0.09)$ & $20(0.91)$ \\
\hline \multicolumn{3}{|l|}{ Diabetic ( $n$ (freq)) } \\
\hline Patients & $0(0)$ & $20(1.0)$ \\
\hline \multicolumn{3}{|c|}{$\mathrm{TG}(\mathrm{mmol} / \mathrm{l})$, median (IQR) } \\
\hline Controls & $1.7(1.47-1.79)$ & $1.35(0.93-2.13)$ \\
\hline Patients & $1.52(1.16-2.06)$ & $1.71(1.1-2.62)$ \\
\hline \multicolumn{3}{|c|}{$\mathrm{TC}(\mathrm{mmol} / \mathrm{l})$, mean (s.D.) } \\
\hline Controls & $6.14(1.15)$ & $5.75(1.27)$ \\
\hline Patients & $5.65(1.64)$ & $5.73(1.54)$ \\
\hline \multicolumn{3}{|c|}{ HDLC (mmol/l), median (IQR) } \\
\hline Controls & $1.03(0.93-1.11)$ & $1.08(0.93-1.27)$ \\
\hline Patients & $0.88(0.69-0.93)$ & $0.77(0.51-1.08)$ \\
\hline \multicolumn{3}{|c|}{ LDLC (mmol/l), mean (S.D.) } \\
\hline Controls & $3.80(0.32)$ & $3.90(1.20)$ \\
\hline Patients & $4.12(1.48)$ & $4.08(1.38)$ \\
\hline \multicolumn{3}{|c|}{ Small dense LDL ( $n$ (freq)) } \\
\hline Controls & $0(0)$ & $5(1.0)$ \\
\hline Patients & $0(0)$ & $17(1.0)$ \\
\hline \multicolumn{3}{|c|}{ NEFA $(\mu \mathrm{mol} / \mathrm{l})$, median (IQR) } \\
\hline Controls & $351.0(350.0-672.0)$ & $467.0(327.0-642.0)$ \\
\hline Patients & $299.0(205.0-486.0)$ & $341.0(131.0-692.0)$ \\
\hline \multicolumn{3}{|c|}{ Lipid lowering ( $n$ (freq)) } \\
\hline Patients & $2(0.11)$ & $17(0.89)$ \\
\hline \multicolumn{3}{|c|}{ hs-CRP (mg/l), median (IQR) } \\
\hline Controls & $2.4(1.95-3.9)$ & $1.5(0.62-2.9)$ \\
\hline Patients & $1.12(0.53-2.73)$ & $2.5(1.5-6.9)$ \\
\hline \multicolumn{3}{|c|}{ Hydrocortisone (mg), median (IQR) } \\
\hline Patients & $25.0(20.0-30.0)$ & $20.0(20.0-30.0)$ \\
\hline \multicolumn{3}{|c|}{ Framingham, median (IQR) } \\
\hline Patients & $8.7(7.4-26.2)$ & $13.7(3.5-22.3)$ \\
\hline \multicolumn{3}{|c|}{ TSH (mIU/l), median (IQR) } \\
\hline Patients & $1.63(0.94-1.84)$ & $1.38(0.76-2.15)$ \\
\hline
\end{tabular}

Both the heterozygous patients and controls respectively exhibited higher TGs and hs-CRP than their wild type counterparts. We observed reduced LDLC with this polymorphism in patients and healthy controls. Heterozygous patients appeared to require higher doses of hydrocortisone, which could be in accordance with the expected effect (glucocorticoid resistance) of this polymorphism. The greatest impact of this polymorphism was on BMI among both the healthy controls and the $\mathrm{AD}$ patients. If this were a true association, we would have expected the GCR gene locus to be strongly linked to obesity in genome-wide association studies (GWAS), as we observed a BMI difference of $2 \mathrm{~kg} / \mathrm{m}^{2}$. GWAS for obesity located SNPs on chromosomes 16 , but not 5 , and were most likely to affect BMI, hip circumference and mass (43). It was expected that the ER22/23EK polymorphism may result in a reduced or unchanged BMI, making our findings counterintuitive. However, the observed increase in BMI in relation to the ER22/23EK polymorphism may also reflect an increase in the muscle mass, as has been previously reported (44). We did not measure body composition in this study and therefore cannot determine whether the raised BMI reflects an increase in muscle or fat mass. The ER22/23EK polymorphism was associated with a reduction in LDLC in healthy controls of 0.47 and $0.58 \mathrm{mmol} / \mathrm{l}$ in $\mathrm{AD}$ patients compared with $0.80 \mathrm{mmol} / \mathrm{l}$ observed by van Rossum et al. (21). Greater reductions in LDLC may be due to the age difference (average age of 40.5 years for healthy control subjects vs 69.2 years in that study) and discrepant mean LDL levels $(3.46 \mathrm{mmol} / \mathrm{l}$ in the healthy controls vs $4.31 \mathrm{mmol} / \mathrm{l}$ ) (21). LDL increases with age, and a higher baseline LDL may be modified to a greater degree by the ER22/23EK polymorphism (45). Beneficial effects on LDLC are not universal and one study confirmed benefit by trend, but failed to reach statistical significance $(21,44,46,47)$. The ER22/23EK polymorphism was rare and it is important to recall that we present only descriptive statistics.

The N363S polymorphism did not appear to alter clinical traits substantially apart from an increase in $\mathrm{BMI}$ in heterozygous controls, compared with controls exhibiting the wild type. Additionally, we noted a slightly greater hydrocortisone dose in patients with this polymorphism, compared with the wild type.

We hypothesised that patients harbouring a sensitising GCR polymorphism may require lower doses of hydrocortisone, whereas those inducing glucocorticoid resistance may require higher doses, due to persistent symptoms of glucocorticoid insufficiency (48). Szczepankiewicz et al. (49) by contrast showed no association between any of the GCR polymorphisms and the need for increased doses of glucocorticoids for asthma. We found very small increases in dose requirements in association with the ER22/23EK, and N363S polymorphisms and AD. However, doses were prescribed on an empiric basis, and symptoms of relative glucocorticoid deficiency are difficult to assess objectively. Moreover, doses were not adjusted by uniform criteria.

The $9 \beta$ polymorphism of the GCR gene was associated with an increased risk of CVD, especially in an elderly subgroup and homozygotes had increased intima media thickness with nearly threefold increased risk of CVD (50); therefore, studying this polymorphism may yield interesting data in our cohort. 


\section{Limitations}

The rarity of $\mathrm{AD}$ limited the size of the study with attendant limitations in the power to detect genotypephenotype associations. The ER 22/23EK and the N363S polymorphisms were rare and the resultant groups were too small for statistically meaningful analysis and thus only descriptive statistics were presented. Type I errors may occur with multiple testing and the true effect should ideally be determined in a homogenous population (51). It is impossible to rule out a false-positive result, whether one does single or multiple tests. Bonferroni's correction involves decreasing the critical $P$ value, reducing the probability of a type I error, but the probability of missing a true association is increased. Most 'correction for multiple testing' approaches are based on an assumption of statistically independent tests. Bonferroni corrections are deemed to be inappropriate in a genetic study such as this, as these SNPs are located very close together on the same gene in linkage disequilibrium with each other, so it is expected to obtain similar associations with all outcomes. There is no consensus on the appropriate $P$ value for testing associations with multiple outcomes with SNPs in linkage disequilibrium, on a single group of individuals. There were missing data and only non-fasted samples were collected. Patients received hydrocortisone at multiple centres and differing dosing regimens could have skewed our data. The optimal study design would have been to study AD patients receiving standardised hydrocortisone doses. Nevertheless, the majority of patients were taking $0.2-0.4 \mathrm{mg} / \mathrm{kg}$ hydrocortisone, to some degree mitigating the lack of a standard hydrocortisone dose. It is conceivable that the dosage could have been adjusted based on both subjective and objective clinical parameters and as such may have induced a degree of bias. We did not take into account the frequency and magnitude of stress dosages before 3 months, which could have had an impact on the body composition and metabolic outcomes in AD. South Africa is an ethnically and genetically diverse society, in which the true effects of a polymorphism may be more difficult to demonstrate. Overall, results should be interpreted cautiously and no specific conclusions should be drawn until corroborated.

\section{Conclusion}

We observed an increase in BMI in healthy controls and patients harbouring the ER22/23EK polymorphism. However, this study was limited by small numbers of patients with this polymorphism and further studies of larger cohorts and analysis of body composition may clarify the effect of this polymorphism on anthropometric measures. Individual hydrocortisone requirements may be influenced by many factors including differences in hydrocortisone absorption and metabolism. GCR polymorphisms may also alter hydrocortisone requirements, but we were unable to show a definite effect in this study. This is likely because of the relatively small size of our study, the rarity of some of the polymorphisms studied, the multiplicity of factors influencing hydrocortisone dose and the non-standardised way in which hydrocortisone was dosed in this study. Our study did, however, demonstrate that patients with $\mathrm{AD}$ often have multiple cardiovascular risk factors and that attention to these risk factors should be an integral element in the care of patients with AD.

\section{Declaration of interest}

G Johannsson has had equity in DuoCort Pharma who developed a modified release formulation and related patents who are currently owned by Viropharma. He acts as a consultant for Viropharma. The other authors declare that they have no conflict of interest.

\section{Funding}

I L Ross is the recipient of the Swedish Research Links Grant No.: $65390 / 2007$. This research has not received funding or any other support from industry.

\section{Author contribution statement}

All the authors contributed substantially to the study design, research and preparation of the manuscript.

\section{References}

1 Bleicken B, Hahner S, Loeffler M, Ventz M, Allolio B \& Quinkler M. Impaired subjective health status in chronic adrenal insufficiency: impact of different glucocorticoid replacement regimens. European Journal of Endocrinology $2008159811-817$. (doi:10.1530/EJE$08-0578$ )

2 Bergthorsdottir R, Leonsson-Zachrisson M, Oden A \& Johannsson G. Premature mortality in patients with Addison's disease: a population-based study. Journal of Clinical Endocrinology and Metabolism 200691 4849-4853. (doi:10.1210/jc.20060076)

3 Chikada N. Imaki T, Hotta M, Sato K \& Takano K. An assessment of bone mineral density in patients with Addison's disease and isolated ACTH deficiency treated with glucocorticoid. Endocrine Journal 200451 355-360. (doi:10.1507/endocrj.51.355)

4 Braatvedt GD, Joyce M, Evans M, Clearwater J \& Reid IR. Bone mineral density in patients with treated Addison's disease. Osteoporosis International $1999 \mathbf{1 0}$ 435-440. (doi:10.1007/ s001980050251)

5 van Raalte DH, Ouwens DM \& Diamant M. Novel insights into glucocorticoid-mediated diabetogenic effects: towards expansion of therapeutic options? European Journal of Clinical Investigation 2009 39 81-93. (doi:10.1111/j.1365-2362.2008.02067.x)

6 Groves RW, Toms GC, Houghton BJ \& Monson JP. Corticosteroid replacement therapy: twice or thrice daily? Journal of the Royal Society of Medicine $1988 \mathbf{8 1} 514-516$.

7 Reaven EP, Kolterman OG \& Reaven GM. Ultrastructural and physiological evidence for corticosteroid-induced alterations in hepatic production of very low density lipoprotein particles. Journal of Lipid Research 197415 74-83. 
8 Hazra A, Pyszczynski NA, DuBois DC, Almon RR \& Jusko WJ. Modeling of corticosteroid effects on hepatic low-density lipoprotein receptors and plasma lipid dynamics in rats. Pharmacological Research 200825 769-780. (doi:10.1007/s11095-007-9371-8)

9 Faggiano A, Pivonello R, Spiezia S, De Martino MC, Filippella M, Di Somma C, Lombardi G \& Colao A. Cardiovascular risk factors and common carotid artery caliber and stiffness in patients with Cushing's disease during active disease and 1 year after disease remission. Journal of Clinical Endocrinology and Metabolism $2003 \mathbf{8 8}$ 2527-2533. (doi:10.1210/jc.2002-021558)

10 Danilowicz K, Bruno OD, Manavela M, Gomez RM \& Barkan A. Correction of cortisol overreplacement ameliorates morbidities in patients with hypopituitarism: a pilot study. Pituitary 200811 279-285. (doi:10.1007/s11102-008-0126-2)

11 Ettinger WH Jr \& Hazzard WR. Prednisone increases very low density lipoprotein and high density lipoprotein in healthy men. Metabolism 198837 1055-1058. (doi:10.1016/0026-0495 (88)90067-4)

12 Bagdade JD, Yee E, Albers J \& Pykalisto OJ. Glucocorticoids and triglyceride transport: effects on triglyceride secretion rates, lipoprotein lipase, and plasma lipoproteins in the rat. Metabolism 197625 533-542. (doi:10.1016/0026-0495(76)90007-X)

13 Chrousos GP, Charmandari E \& Kino T. Glucocorticoid action networks - an introduction to systems biology. Journal of Clinical Endocrinology and Metabolism 200489 563-564. (doi:10.1210/ jc.2003-032026)

14 Encio IJ \& Detera-Wadleigh SD. The genomic structure of the human glucocorticoid receptor. Journal of Biological Chemistry $19912667182-7188$.

15 Voorhoeve PG, van den Akker EL, van Rossum EF, Koper JW, van Mechelen W, Lamberts SW \& Delemarre-van de Waal HA. Glucocorticoid receptor gene variant is associated with increased body fatness in youngsters. Clinical Endocrinology 200971 518-523. (doi:10.1111/j.1365-2265.2009.03538.x)

16 Kuningas M, Mooijaart SP, Slagboom PE, Westendorp RG \& van Heemst D. Genetic variants in the glucocorticoid receptor gene (NR3C1) and cardiovascular disease risk. The Leiden 85-plus Study. Biogerontology 20067 231-238. (doi:10.1007/s10522 006-9021-2)

17 Lin RC, Wang XL \& Morris BJ. Association of coronary artery disease with glucocorticoid receptor N363S variant. Hypertension $2003 \mathbf{4 1}$ 404-407. (doi:10.1161/01.HYP.00000 55342.40301.DC)

18 Di Blasio AM, van Rossum EF, Maestrini S, Berselli ME, Tagliaferri M, Podesta F, Koper JW, Liuzzi A \& Lamberts SW. The relation between two polymorphisms in the glucocorticoid receptor gene and body mass index, blood pressure and cholesterol in obese patients. Clinical Endocrinology $2003 \quad 59$ 68-74. (doi:10.1046/j.1365-2265.2003.01798.x)

19 Lin RC, Wang WY \& Morris BJ. High penetrance, overweight, and glucocorticoid receptor variant: case-control study. BMJ 1999 319 1337-1338. (doi:10.1136/bmj.319.7221.1337)

20 Marti A, Ochoa MC, Sanchez-Villegas A, Martinez JA, MartinezGonzalez MA, Hebebrand J, Hinney A \& Vedder H. Meta-analysis on the effect of the N363S polymorphism of the glucocorticoid receptor gene (GRL) on human obesity. BMC Medical Genetics 20067 50. (doi:10.1186/1471-2350-7-50)

21 van Rossum EF, Koper JW, Huizenga NA, Uitterlinden AG, Janssen JA, Brinkmann AO, Grobbee DE, de Jong FH, van Duyn CM, Pols HA et al. A polymorphism in the glucocorticoid receptor gene, which decreases sensitivity to glucocorticoids in vivo, is associated with low insulin and cholesterol levels. Diabetes 200251 3128-3134. (doi:10.2337/diabetes.51.10. 3128)

22 Bertalan R, Patocs A, Boyle B, Rigo J \& Racz K. The protective effect of the ER22/23EK polymorphism against an excessive weight gain during pregnancy. Gynecological Endocrinology 2009 25 379-382. (doi:10.1080/09513590902730762)

23 Manenschijn L, van den Akker EL, Lamberts SW \& van Rossum EF. Clinical features associated with glucocorticoid receptor polymorphisms. An overview. Annals of the New York Academy of Sciences 2009 1179 179-198. (doi:10.1111/j.1749-6632.2009. 05013.x)

24 Lei SF, Deng FY, Liu XH, Huang QR, Qin Y, Zhou Q, Jiang DK, Li YM, Mo XY, Liu MY et al. Polymorphisms of four bone mineral density candidate genes in Chinese populations and comparison with other populations of different ethnicity. Journal of Bone and Mineral Metabolism 200321 34-42. (doi:10.1007/ s007740300006)

25 Russcher H, Smit P, van den Akker EL, van Rossum EF, Brinkmann AO, de Jong FH, Lamberts SW \& Koper JW. Two polymorphisms in the glucocorticoid receptor gene directly affect glucocorticoid-regulated gene expression. Journal of Clinical Endocrinology and Metabolism 200590 5804-5810. (doi:10.1210/jc.2005-0646)

26 Huizenga NA, Koper JW, De Lange P, Pols HA, Stolk RP, Burger H, Grobbee DE, Brinkmann AO, De Jong FH \& Lamberts SW. A polymorphism in the glucocorticoid receptor gene may be associated with and increased sensitivity to glucocorticoids in vivo. Journal of Clinical Endocrinology and Metabolism $1998 \mathbf{8 3}$ 144-151. (doi:10.1210/jc.83.1.144)

27 Gidez LI, Miller GJ, Burstein M, Slagle S \& Eder HA. Separation and quantitation of subclasses of human plasma high density lipoproteins by a simple precipitation procedure. Journal of Lipid Research 198223 1206-1223.

28 Friedewald WT, Levy RI \& Fredrickson DS. Estimation of the concentration of low-density lipoprotein cholesterol in plasma, without use of the preparative ultracentrifuge. Clinical Chemistry 197218 499-502.

29 Wilson PW, D'Agostino RB, Levy D, Belanger AM, Silbershatz H \& Kannel WB. Prediction of coronary heart disease using risk factor categories. Circulation 199897 1837-1847. (doi:10.1161/01. CIR.97.18.1837)

30 Yeo WW \& Yeo KR. Predicting CHD risk in patients with diabetes mellitus. Diabetic Medicine 200118 341-344. (doi:10.1046/ j.1464-5491.2001.00510.x)

31 Gustafson S, Proper JA, Bowie EJ \& Sommer SS. Parameters affecting the yield of DNA from human blood. Analytical Biochemistry 1987165 294-299. (doi:10.1016/0003-2697 (87)90272-7)

32 Giordano R, Marzotti S, Berardelli R, Karamouzis I, Brozzetti A, D'Angelo V, Mengozzi G, Mandrile G, Giachino D, Migliaretti G et al. BClI polymorphism of the glucocorticoid receptor gene is associated with increased obesity, impaired glucose metabolism and dyslipidaemia in patients with Addison's disease. Clinical Endocrinology 201277 863-870. (doi:10.1111/j.1365-2265. 2012.04439.x)

33 Assmann G, Schulte H, Funke H \& von Eckardstein A. The emergence of triglycerides as a significant independent risk factor in coronary artery disease. European Heart Journal 1998 19 M8-M14.

34 Yuan G, Al-Shali KZ \& Hegele RA. Hypertriglyceridemia: its etiology, effects and treatment. CMAJ: Canadian Medical Association Journal 2007 176 1113-1120. (doi:10.1503/cmaj.060963)

35 van der Westhuyzen DR, de Beer FC \& Webb NR. HDL cholesterol transport during inflammation. Current Opinion in Lipidology 2007 18 147-151. (doi:10.1097/MOL.Ob013e328051b4fe)

36 Beentjes JA, van Tol A, Sluiter WJ \& Dullaart RP. Decreased plasma cholesterol esterification and cholesteryl ester transfer in hypopituitary patients on glucocorticoid replacement therapy. Scandinavian Journal of Clinical and Laboratory Investigation 2000 60 189-198. (doi:10.1080/003655100750044839)

37 Bjornheden T, Babyi A, Bondjers G \& Wiklund O. Accumulation of lipoprotein fractions and subfractions in the arterial wall, determined in an in vitro perfusion system. Atherosclerosis 1996 123 43-56. (doi:10.1016/0021-9150(95)05770-6)

38 Monteiro CM, Pinheiro LF, Izar MC, Barros SW, Vasco MB, Fischer SM, Povoa RM, Brandao SA, Santos AO, Oliveira L et al. Highly sensitive C-reactive protein and male gender are independently related to the severity of coronary disease in patients with 
metabolic syndrome and an acute coronary event. Brazilian Journal of Medical and Biological Research 201043 297-302. (doi:10.1590/S0100-879X2010005000008)

39 Donn R, Payne D \& Ray D. Glucocorticoid receptor gene polymorphisms and susceptibility to rheumatoid arthritis. Clinical Endocrinology 200767 342-345. (doi:10.1111/j.1365-2265. 2007.02887.x)

40 Decorti G, De Iudicibus S, Stocco G, Martelossi S, Drigo I, Bartoli F \& Ventura A. Glucocorticoid receptor polymorphisms in inflammatory bowel disease. Gut 200655 1053-1054.

41 De Iudicibus S, Stocco G, Martelossi S, Drigo I, Norbedo S, Lionetti P, Pozzi E, Barabino A, Decorti G, Bartoli F et al. Association of BclI polymorphism of the glucocorticoid receptor gene locus with response to glucocorticoids in inflammatory bowel disease. Gut 2007 56 1319-1320. (doi:10.1136/gut.2006.116160)

42 Lee EB, Kim JY, Lee YJ \& Song YW. Glucocorticoid receptor polymorphisms in Korean patients with rheumatoid arthritis. Annals of the Rheumatic Diseases 200564 503-504. (doi:10.1136/ard.2004.023432)

43 Scuteri A, Sanna S, Chen WM, Uda M, Albai G, Strait J, Najjar S, Nagaraja R, Orru M, Usala G et al. Genome-wide association scan shows genetic variants in the FTO gene are associated with obesity-related traits. PLoS Genetics 20073 e115. (doi:10.1371/ journal.pgen.0030115)

44 van Rossum EF, Voorhoeve PG, te Velde SJ, Koper JW, Delemarrevan de Waal HA, Kemper HC \& Lamberts SW. The ER22/23EK polymorphism in the glucocorticoid receptor gene is associated with a beneficial body composition and muscle strength in young adults. Journal of Clinical Endocrinology and Metabolism $2004 \mathbf{8 9}$ 4004-4009. (doi:10.1210/jc.2003-031422)

45 Hahn C, Hofmann A \& von Bergmann K. The age-related increase in LDL cholesterol is not a result of reduced bile acid synthesis. Atherosclerosis 1995115 S78. (doi:10.1016/00219150(95)96548-7)
46 Raef H, Baitei EY, Zou M \& Shi Y. Genotype-phenotype correlation in a family with primary cortisol resistance: possible modulating effect of the ER22/23EK polymorphism. European Journal of Endocrinology 2008158 577-582. (doi:10.1530/EJE-07-0629)

47 van Rossum EF, Feelders RA, van den Beld AW, Uitterlinden AG, Janssen JA, Ester W, Brinkmann AO, Grobbee DE, de Jong FH, Pols HA et al. Association of the ER22/23EK polymorphism in the glucocorticoid receptor gene with survival and C-reactive protein levels in elderly men. American Journal of Medicine 2004 117 158-162. (doi:10.1016/j.amjmed.2004.01.027)

48 Arlt W, Rosenthal C, Hahner S \& Allolio B. Quality of glucocorticoid replacement in adrenal insufficiency: clinical assessment vs. timed serum cortisol measurements. Clinical Endocrinology 200664 384-389.

49 Szczepankiewicz A, Breborowicz A, Sobkowiak P \& Popiel A. No association of glucocorticoid receptor polymorphisms with asthma and response to glucocorticoids. Advances in Medical Sciences 2008 53 245-250. (doi:10.2478/v10039-008-0042-8)

50 van den Akker EL, Koper JW, van Rossum EF, Dekker MJ, Russcher H, de Jong FH, Uitterlinden AG, Hofman A, Pols HA, Witteman JC et al. Glucocorticoid receptor gene and risk of cardiovascular disease. Archives of Internal Medicine 2008168 33-39. (doi:10.1001/archinternmed.2007.41)

51 van Rossum EF, Russcher H \& Lamberts SW. Genetic polymorphisms and multifactorial diseases: facts and fallacies revealed by the glucocorticoid receptor gene. Trends in Endocrinology and Metabolism 200516 445-450. (doi:10.1016/j.tem.2005.10.009)

Received 13 September 2012

Revised version received 6 December 2012

Accepted 12 December 2012 